\title{
500,000 Years of Environmental History in Eastern Anatolia: The PALEOVAN Drilling Project
}

\author{
by Thomas Litt, Flavio S. Anselmetti, Henrike Baumgarten, Jürg Beer, Namik Cagatay, Deniz Cukur, \\ Emre Damci, Clemens Glombitza, Gerald Haug, Georg Heumann, Jens Kallmeyer, Rolf Kipfer, \\ Sebastian Krastel, Ola Kwiecien, A. Feray Meydan, Sefer Orcen, Nadine Pickarski, \\ Marie-Eve Randlett, Hans-Ulrich Schmincke, Carsten J. Schubert, Mike Sturm, \\ Mari Sumita, Mona Stockhecke, Yama Tomonaga, Luigi Vigliotti, \\ Thomas Wonik, and the PALEOVAN Scientific Team
}

doi:10.2204/iodp.sd.14.02.2012

\begin{abstract}
International Continental Scientific Drilling Program (ICDP) drilled a complete succession of the lacustrine sediment sequence deposited during the last $\sim 500,000$ years in Lake Van, Eastern Anatolia (Turkey). Based on a detailed seismic site survey, two sites at a water depth of up to $360 \mathrm{~m}$ were drilled in summer 2010, and cores were retrieved from sub-lake-floor depths of $140 \mathrm{~m}$ (Northern Basin) and $220 \mathrm{~m}$ (Ahlat Ridge). To obtain a complete sedimentary section, the two sites were multiple-cored in order to investigate the paleoclimate history of a sensitive semi-arid region between the Black, Caspian, and Mediterranean seas. Further scientific goals of the PALEOVAN project are the reconstruction of earthquake activity, as well as the temporal, spatial, and compositional evolution of volcanism as reflected in the deposition of tephra layers. The sediments host organic matter from different sources and hence composition, which will be unravelled using biomarkers. Pathways for migration of continental and mantle-derived noble gases will be analyzed in pore waters. Preliminary $40 \mathrm{Ar} / 39 \mathrm{Ar}$ single crystal dating of tephra layers and pollen analyses suggest that the Ahlat Ridge record encompasses more than half a million years of paleoclimate and volcanic/geodynamic history, providing
\end{abstract}

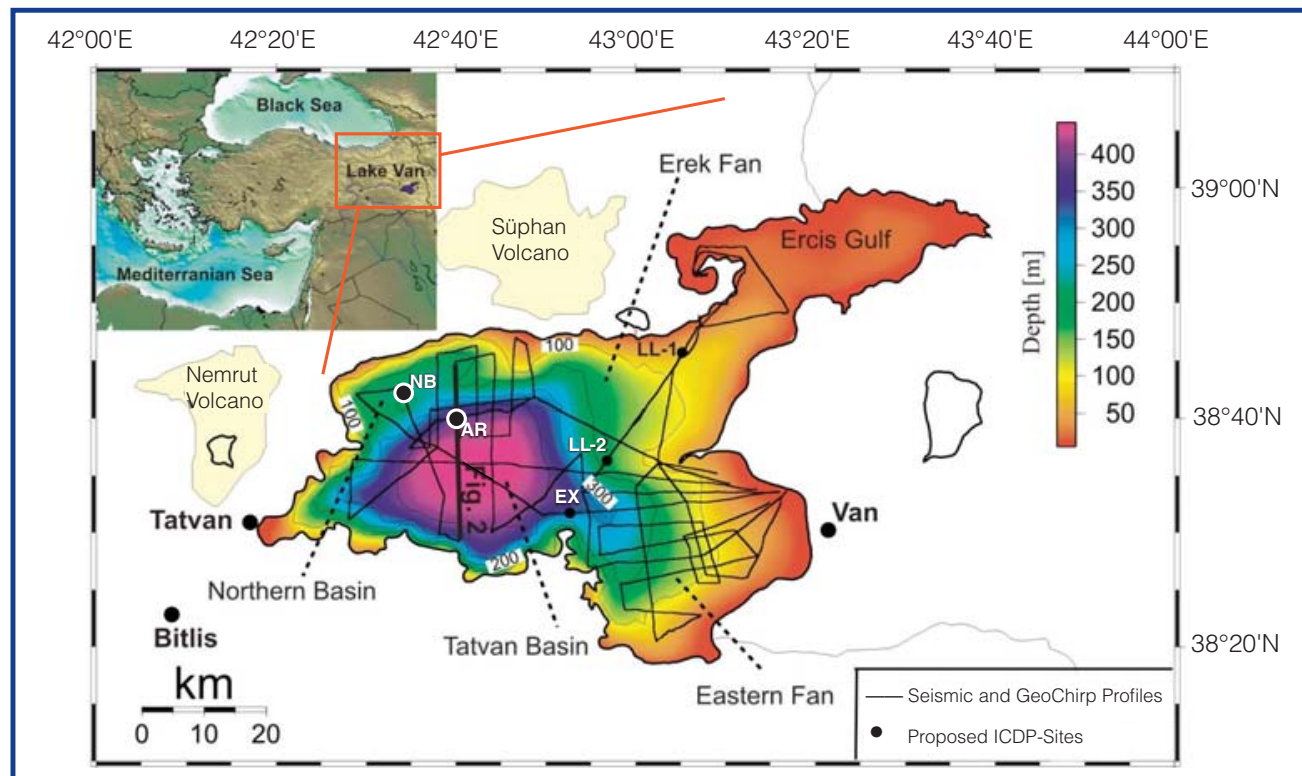

Figure 1. Bathymetric map of Lake Van with location of available seismic profiles and originally proposed drill sites. Ahlat Ridge (AR) and Northern Basin (NB) were finally drilled. the longest continental record in the entire Near East to date.

\section{Background and Motivation}

The controversial discussion of present and future global warming has demonstrated that it is crucial to increase our knowledge of past climate change to better understand the pattern and dynamics of the global climate system. In continental regions this information can be obtained from lacustrine sediments, where biotic and abiotic parameters provide proxy climate data. In addition, lake sediments constitute unique paleoenvironmental archives storing also information of geologic disasters such as earthquakes or volcanic eruptions. Lake Van in Turkey is an excellent paleoclimate and paleoenvironmental archive, as site survey data indicated that it contains a long continental sedimentary record covering several glacial-interglacial cycles consisting partly of annually-laminated sediments.

Favorable geological conditions in the eastern Mediterranean and the Near East, such as relatively undisturbed accumulation of continuous Quaternary sediments, are rare. Successions such as the pollen records from Tenagi Phillipon and Joannina in Greece (Tzedakis et al., 2001) or from Lake Urmia in NW Iran (Djamali et al., 2008) document climatic changes over the continent on centennial to orbital time scales. These sequences enabled tentative comparisons with the marine isotopic record based on tuning to astronomical parameters, and showed that many stages and substages of the marine isotopic sequence are reflected in continental records. However, the timing of the transitions between them may not be precisely synchronous in the marine and continental realms. Lake Van holds a key position within 
a sensitive climate region between the Mediterranean, Black, Caspian, and Arabian seas allowing for studying Quaternary climate evolution in the Near East during the last 500 kyr (Litt et al., 2009, 2011). The Lake Van record drilled in 2010 is longer than those of Lake Urmia and Lake Joannina. In addition, the Van record will have a higher resolution and will be better dated than all of these previous records.

Lake Van, situated on a high plateau in eastern Anatolia, extends $\sim 130 \mathrm{~km}$ WSW-ENE (Fig. 1). The lake level at present is 1647 $\mathrm{m}$ above sea level (a.s.1.)

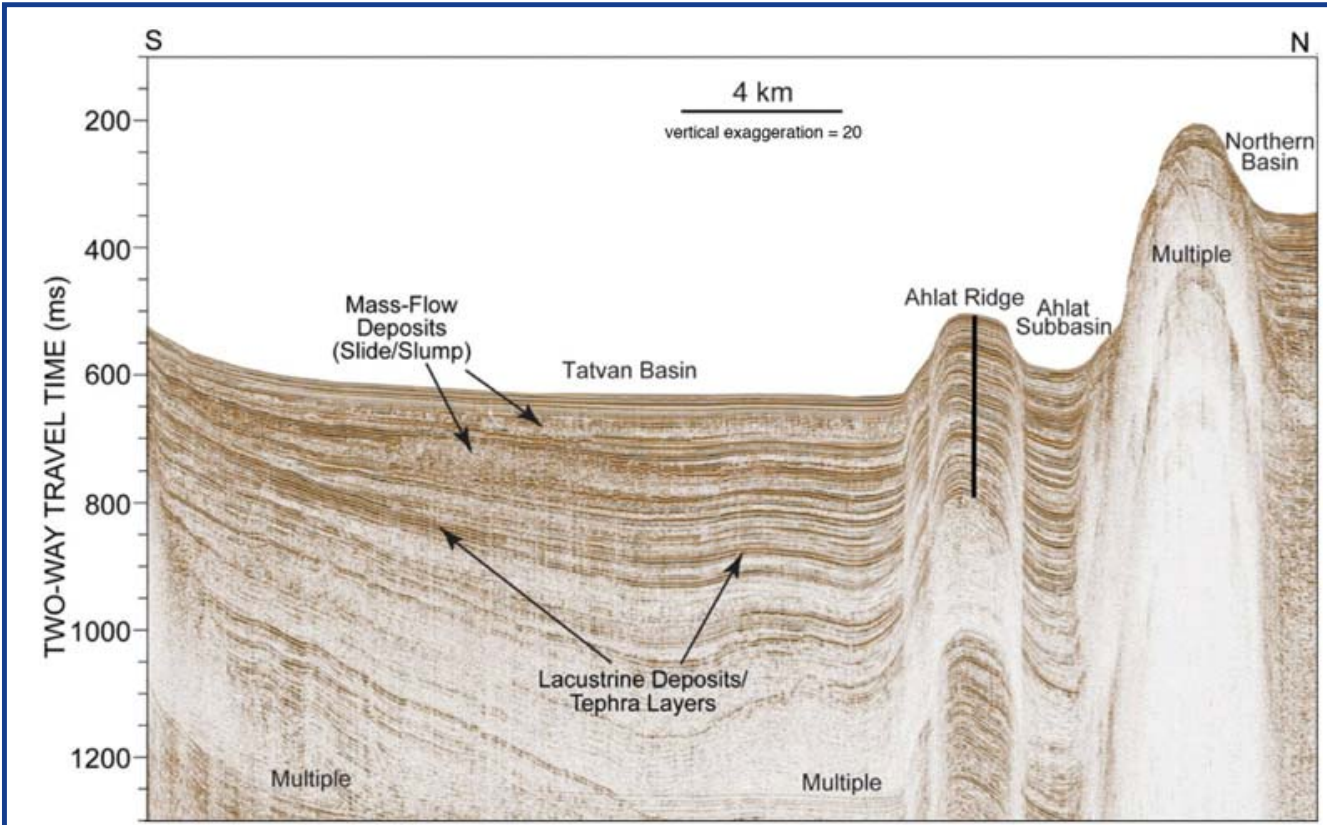

Figure 2. Seismic profile crossing the Tatvan Basin, Ahlat Ridge, and Northern Basin. Ahlat Ridge was selected as key site for the ICDP campaign in order to drill recover a complete sedimentary section for paleoclimatic investigations all the way to basement. See Fig. 1 for location of profile.

As the fourth largest (by

volume) terminal lake in the world and largest soda lake (607 km³ , maximum depth $460 \mathrm{~m}$; Kadioglu et al., 1997), it is situated in a region where the Afro/Arabian Plate from the south meets the Eurasian Plate from the north and east. Lake Van fills a tectonic depression within an active fault system that is the cause of regional volcanism and seismic as well as hydrothermal activity (Degens and Kurtman, 1978; Keskin, 2003; Kipfer et al., 1994; Litt et al., 2009; Șengör et al., 2003). Evaporation processes, hydrothermal activity, and chemical weathering of volcanic rocks, together with a supply of alkaline tephra into the lake basin, are responsible for the extreme alkalinity of the lake water ( $\mathrm{pH} 9.8$, salinity $21.4 \%$ ). Two active volcanoes Nemrut (3050 m a.s.1.) and Süphan (4058 $\mathrm{m}$ a.s.1.) rise in the immediate vicinity of the lake (Fig. 1).

The lake's position in a semiarid area at the junction of the atmospheric southwestern jet stream and northern branch of the Subtropical High makes it climatically sensitive. The jet stream steers the cyclone tracks that are responsible for supplying moisture from Mediterranean air masses during winter. The location of the Subtropical High controls the southward exten- sion of the dry continental air masses of northeastern Europe and Asia (Litt et al., 2009).

Terminal and saline, Lake Van reacts very sensitively to lake-level changes caused by any alterations in the hydrological regime in response to climate change. Subaerial paleoshorelines and sedimentological evidence show that the lake level fluctuated up to several hundred meters in the past (Landmann et al., 1996; Lemcke and Sturm, 1997). No erosional unconformity could be detected in the younger lacustrine sections on seismic data below $250 \mathrm{~m}$ water depth, limiting the maximum lake-level drop to that depth. These

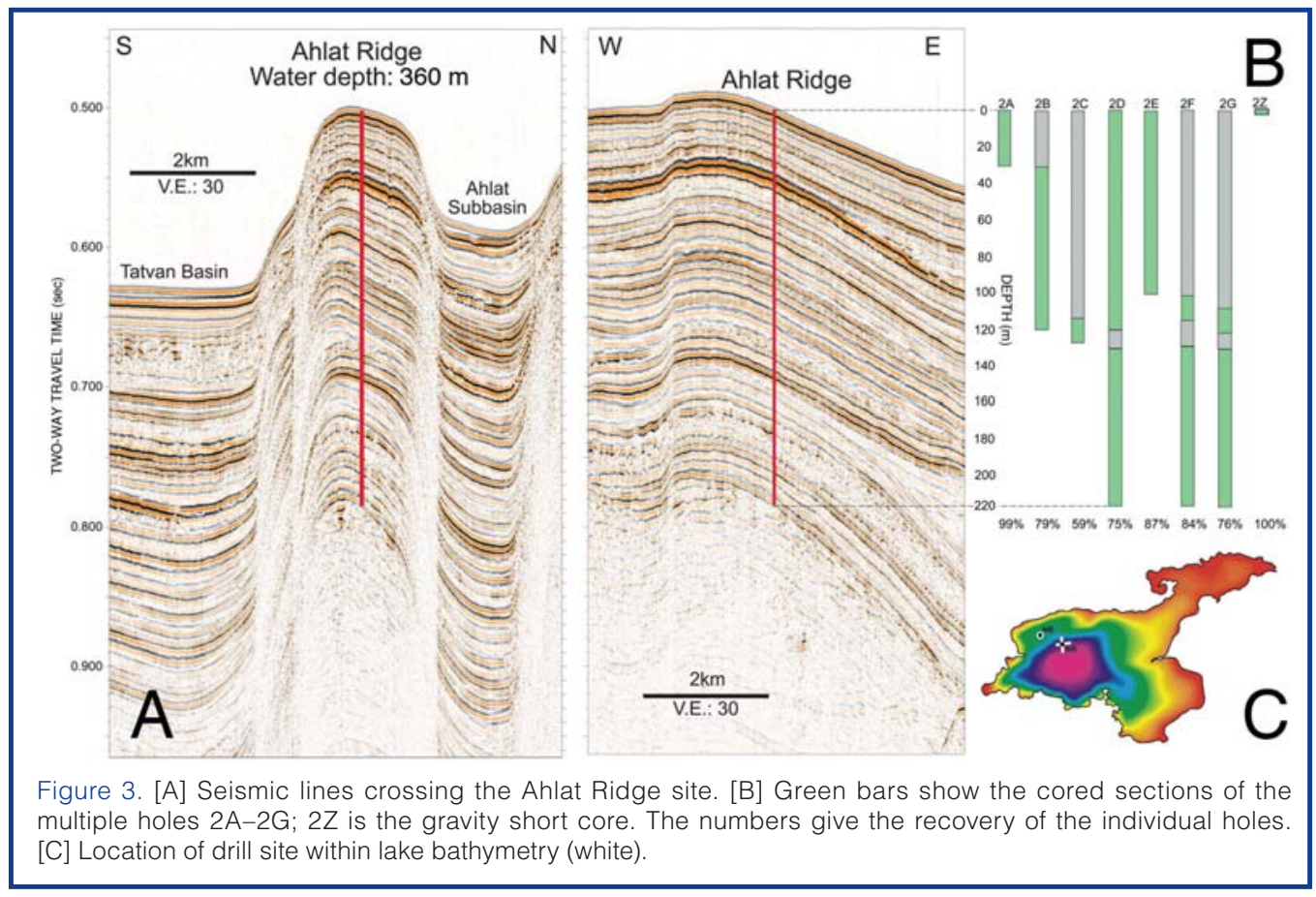


lake-level changes are sensitively recorded in the lithological and geochemical composition of Lake Van sediments and in the pore-water geochemistry. In particular, the oxygen isotopic composition of the bulk carbonate, consisting of almost pure authigenic aragonite, provides a powerful proxy to track the lake-level fluctuations during the last 15-20 kyr (Lemcke and Sturm, 1997; Litt et al., 2009; Wick et al., 2003). Such a dominance of authigenic carbonate precipitation is also expected from the older sedi-

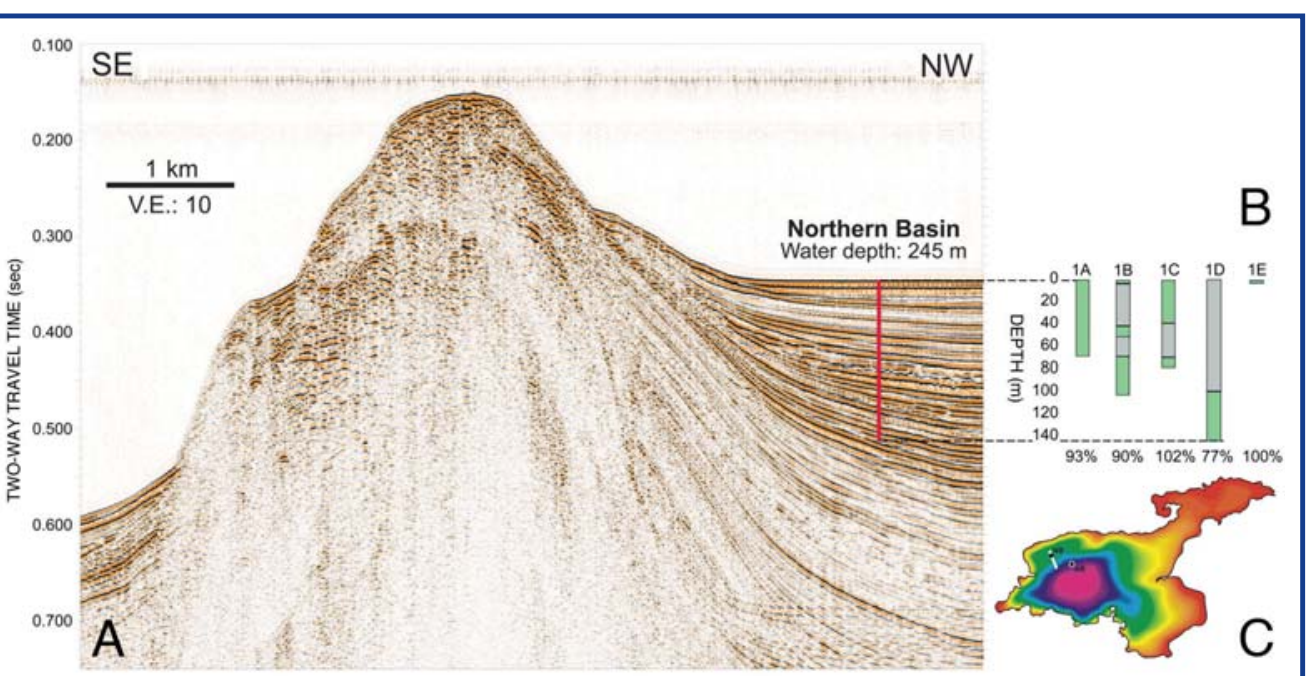

Figure 4. [A] Seismic line crossing the Northern Basin site. [B] Green areas show the cored sections of the multiple holes $1 \mathrm{~A}-1 \mathrm{D} ; 1 \mathrm{E}$ is the gravity short core. The numbers give the recovery of the individual holes (values $>100 \%$ caused by gas expansion). [C] Location of drill site within lake bathymetry (white). mentary succession, so that

isotope geochemical studies will be the tool of choice for reconstructing the past precipitation/evaporation ratio.

The Lake Van area is strongly affected by earthquakes, a catastrophical natural hazard in the region. An earthquake with a magnitude of 7.2 just north of the city of Van on 23 October 2011 caused more than 600 casualties and major infrastructural damage in the region. In order to investigate recurrence rates of such events and to support seismic hazard studies, long paleoseismic records are needed that document the succession of strong earthquakes and past seismic activities for this tectonically active area. Short sedi-

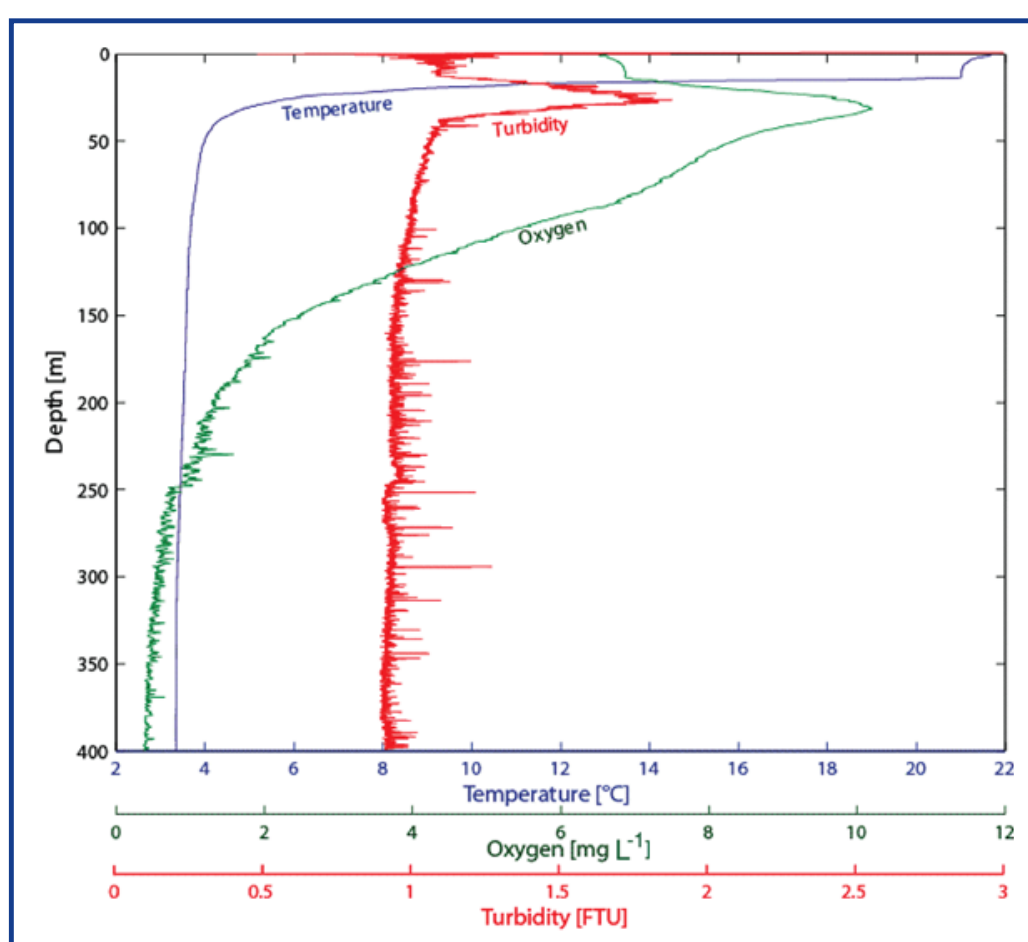

Figure 5. Temperature, turbidity (Formazin Turbidity Units), and oxygen profiles acquired with a CTD probe at the Tatvan Basin mooring site on 28 August 2009 (from Stockhecke et al., 2012). Note that oxygen content is not calibrated, in particular at lower concentrations. ment cores obtained in 2004 also show strong evidence of earthquake-triggered microfaults, which can be interpreted as seismites (Litt et al., 2009). Consequently, one goal of the PALEOVAN drilling project (http:www.paleovan.info/) was to establish an extended paleoseismic event catalogue on the basis of the deep drill cores.

A major benefit of choosing Lake Van as a drill site was the likelihood of recovering several hundred tephra layers from the active Nemrut and Süphan volcanoes towering Lake Van (Fig. 1), which would provide a tephrostratigraphic framework and allow single-crysta ${ }^{40} \mathrm{Ar} /{ }^{39} \mathrm{Ar}$ dating. Pre-site work has documented several tens of fallout and flow deposits originating mainly from the alkaline Nemrut volcano, including some eruptions of large magnitude (Sumita et al., 2012). Nemrut volcano has been active in historical times, and future eruptions are likely; therefore, knowledge of its past activity is critical to evaluate the current volcanic hazard.

Due to its unique geological and tectonic settings, Lake Van accumulates helium from a depleted Earth mantle source (Kipfer et al., 1994). On regional scales, such a release and transport of He from the solid Earth into the atmosphere is poorly understood. As lakes cover larger areas, they become prime targets to analyze the transport and release mechanism of terrestrial He from the solid Earth. The long profile from Lake Van will allow determination of the in situ terrestrial He gradient as a function of depth within a sediment column of several hundred meters. These data will provide the first direct insights into the transport processes of crustal and mantle He through the uppermost layers of the crust and improve the cur- 


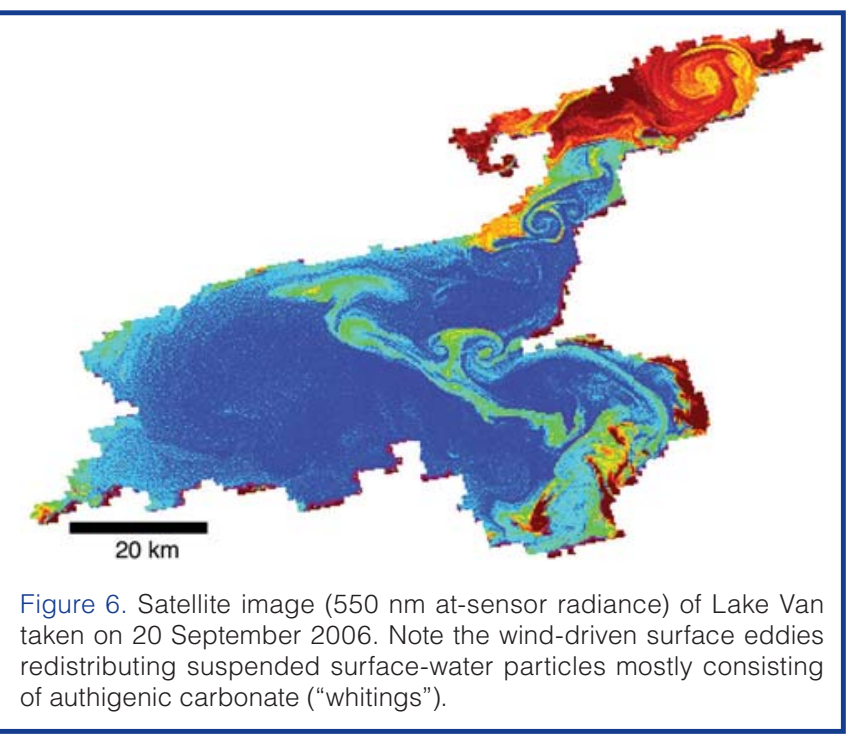

rent understanding of terrestrial fluid transport within the continental crust.

\section{Site Surveys}

\section{Reflection Seismic Surveys}

A seismic site survey at Lake Van was carried out in 2004 (Litt et al., 2009). In total we collected fifty profiles with a length of $~ 850 \mathrm{~km}$ by means of a high-resolution multi-channel and GeoChirp system (Fig. 1). Three physiographic provinces can be identified based on the seismic data: a lacustrine shelf, a lacustrine slope, and a deep, relatively flat lake basin province (Figs. 1, 2).

The lake has two prominent basins (Tatvan and Northern Basins; Fig. 1), separated by basement rises or ridges. The seismic units in the Tatvan and Northern Basins are largely characterized by an alternating succession of well-stratified and chaotic reflections (Fig. 2). The chaotic seismic facies are interpreted as slump and slide deposits, which were triggered by quick lake-level fluctuations and/or earthquakes. The moderate-to-high-amplitude, well-stratified facies seen in the deep parts of the basins are interpreted as background lacustrine deposits and tephra layers.

The most prominent features of the lacustrine shelf and slope are prograding deltaic sequences, numerous unconformities, submerged channels, as well as closely spaced U- and/or V-shaped depressions (Litt et al., 2009), reflecting the variable lake-level history of Lake Van. Seven clinoform units that are found in the Eastern Fan (Fig. 1) possibly represent relict deltas formed during periods of stationary or slightly rising lake levels. Various volcanic intrusions and extrusions have been identified in the southern part of the lake. Their occurrence closely follows the trend of the northern thrust fault, suggesting a close relationship between the thrust faulting and the volcanic activity.

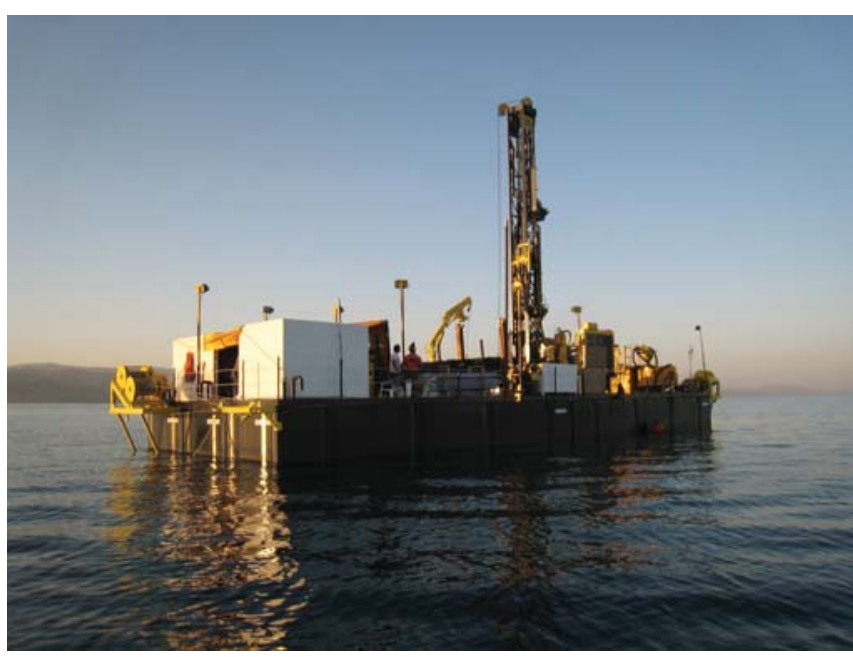

Figure 7. The new large Deep Lake Drilling System (DLDS) operated by DOSECC with the new top-head-drive rotary rig.

Based on the high-resolution seismic data collected in 2004, five primary sites were selected (Fig. 1). The Ahlat Ridge site (AR) is the deepest (water depth $\sim 360 \mathrm{~m}$ ) and most important one (Figs. 1, 3), drilled in order to recover a complete sedimentary section for paleoclimatic investigations. The AR site is located on a sedimentary ridge preventing accumulation of mass-transport deposits, which are widespread in the Tatvan Basin (Fig. 2). On the other hand, the detailed analysis of the seismic data shows that a continuous sedimentary succession without major hiatuses can be drilled at this location down to at least $220 \mathrm{~m}$ subsurface depth (Fig. 3).The Northern Basin site (NB) is close to the northern shore of Lake Van (Figs. 1, 2, 4). The proximity to the Süphan and Nemrud volcanoes allows for studying major volcanic eruptions and associated volcanogenic hazards.

Only these two sites were drilled in 2010. Three additional sites were proposed, but their drilling was canceled due to financial limitations. Two sites in different water depths at the Erek Fan (LL-1 and LL-2) were planned to investigate lake-level fluctuations and the evolution of Lake Van. Finally, one site (EX) was proposed to examine the origin of widespread extrusions and intrusions, which are important for the tec-tonic setting of the lake.

\section{Monitoring Modern Limnology}

Next to the geophysical site surveys, several limnologic and short-coring campaigns as well as remote-sensing data analysis were undertaken. Numerous conductivity, temperature, and depth (CTD) profiles documented the stratification and mixing behavior of the lake (Fig. 5). The turbidity profile from a late summer profile (Fig. 5) shows a thick layer of suspended particles in the metalimnion at 15-40 m depth accompanied by an oxygen maximum, both indicative of algal blooms and carbonate precipitation. Below, oxygen concentration decreased with depth, and at $\sim 250 \mathrm{~m}$ water depth, a drop in oxygen concentration combined with a rise in turbidity can be interpreted as a transition from oxic to 
anoxic water conditions (Kaden et al., 2010). Satellite data from the different seasons image the wind-driven surface currents of the lake, distributing particles in several eddies (Fig. 6; Stockhecke et al., 2012). The reflectance of the water mostly indicates differences in concentrations of suspended particles from ongoing authigenic carbonate precipitation ("whitings"). The annual particle cycle has been further documented in three years of sediment-trap data. It was shown that carbonate precipitation usually occurs in spring and fall, when runoff (snowmelt and precipitation) supplies $\mathrm{Ca}$ ions, which favor carbonate precipitation (Stockhecke et al., 2012). In winter, the fine-grained suspended material (organic and clay particles) settle and form the dark laminae of the varved layers, so that Lake Van sediments provide an annually layered sediment archive (Landmann et al., 1996; Litt et al., 2009, 2011; Wick et al., 2003). Sediment-trap data also documented the annual cycles in biomarkers as well as in terrestrial supply (Huguet et al., 2011, 2012).

\section{Drilling Operations}

\section{Core Drilling and Recovery}

The ICDP drilling operation was carried out from 2 July to 23 August 2010. As operator of the deep drilling, the U.S. corporation DOSECC (Drilling, Observation and Sampling of the Earth's Continental Crust) developed and assembled a new Deep Lake Drilling System (DLDS). It was specifically designed for coring sediments from deep lakes, and it made its maiden voyage on Lake Van. The DLDS consists of two main parts: the barge and the drilling rig. The barge is a modular system constructed with six separate containers connected in a two-by-three configuration (24.4 m long, 7.3 m wide). The drill rig (Atlas Copco T3WDH) is a top-headdrive rotary rig. The platform also accommodates drilling pipes, mud tanks, a science lab, and a driller's shack. In order to securely set the anchors in water depths of more than $400 \mathrm{~m}$, a $2 \times 2$ containers large platform was equipped

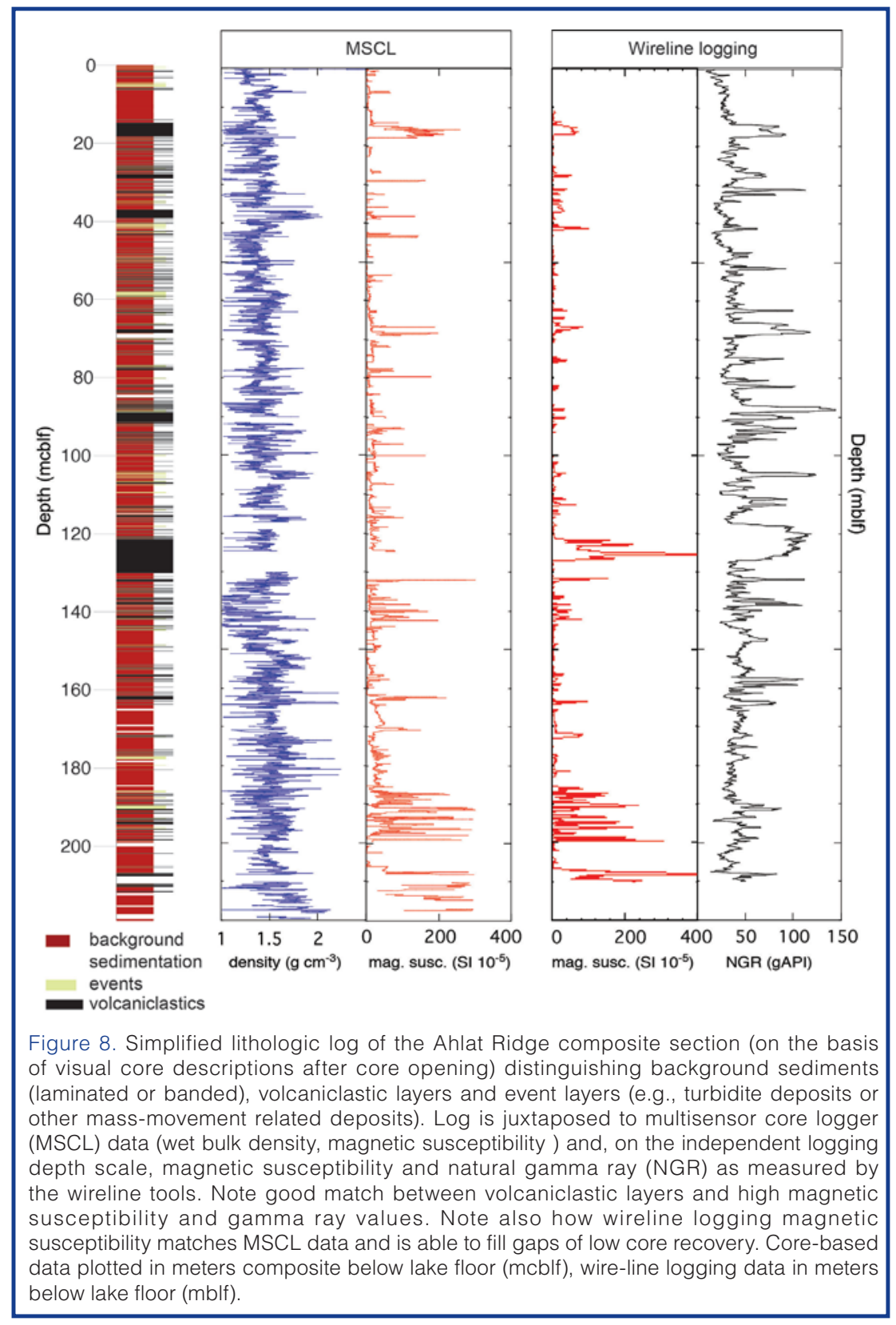
with a hydraulic winch which served as an additional barge during anchoring operations. During the campaign, two drill and two science teams worked in two 12-hour shifts on the platform, and one science team worked in a shore-based lab. During the shift changes, the cores were transported to the shore and stored in a cooling container at $4^{\circ} \mathrm{C}$. The DOSECC drill barge operated in Lake Van at water depths of up to $360 \mathrm{~m}$, and cores from sub-lake-floor depths of $140 \mathrm{~m}$ (NB) and 220 $\mathrm{m}$ (AR) depth were retrieved, the latter reaching the bedrock at the base of the lacustrine succession as predicted by the seismic data. To obtain a complete sedimentary section, the two sites were multiple-cored (Figs. 3, 4). An average recovery of the cored sections of $91 \%$ has been obtained at the AR site and of $71 \%$ at the NB site. The length of the total recovered cores is over $800 \mathrm{~m}$.

\section{Downhole Logging Operations}

Downhole logging was performed in Hole $2 \mathrm{D}$ at the AR site (to $212 \mathrm{~m}$ depth) and in Hole $1 \mathrm{D}$ at the $\mathrm{NB}$ site (to $127 \mathrm{~m}$ depth). Due to borehole instability, the slimhole tools were lowered into the holes through the drill pipes, and several sections of overlapping 15-105-m-long open hole intervals were measured. Continuous data sets of downhole data (spectral gamma ray, magnetic susceptibility [Fig. 8]; dipmeter, resistivity, and temperature as well as partly sonic data) were achieved at both sites. Additionally, vertical seismic profiling at the AR site was carried out by use of an airgun source and a threecomponent geophone. 
The logging-data quality is high, and in particular natural radioactivity (natural gamma ray, K, U, Th-contents), susceptibility (Fig. 8), and resistivity show strong variations, which are promising for further interpretations. Characterization of the physical properties of the lithologies by use of multivariate statistics (cluster analysis) and comparison with results of the core description is ongoing. Of particular interest are variations of physical properties within the tephra deposits, which will be linked to volcanic composition and volcanic source.

\section{Onsite Laboratory Analyses}

\section{MSCL Core Scanning}

First core analyses were performed in an onshore laboratory in a 24-hour fashion, following the general concept utilized in similar drilling projects (Melles et al., 2011, 2012; Ohlendorf et al., 2011). A multisensor core logger (MSCL) measured all recovered core sections and yielded wet bulk density, magnetic susceptibility, and p-wave velocity data at a vertical spacing of $1 \mathrm{~cm}$ (Fig. 8). These data were used to establish a rough composite section between the different holes at each site, so that drilling operations could be guided in real time in order to have as few gaps as possible in the final composite section. Correlations between the sites were communicated directly to the drilling platform, where presumed overlaps between previously drilled cores were taken into consideration when deciding ideal overlapping drives for the ongoing coring operations. The minimal number of gaps of the resulting composite section (Fig. 8) reflects the usefulness of this critical onsite capability.

\section{Core-Catcher Samples and Pore Waters}

The recovered sediment cores were not opened until the core-opening parties at the Integrated Ocean Drilling Program (IODP) Bremen core repository. Core catchers, spaced usually every three meters, provided the available sample material for onsite lithologic descriptions. Smear slides and visual inspections of core-catcher material yielded the first indications of sediment composition, i.e., the distributions of volcanic, detrital, authigenic (carbonate) and biogenic (e.g., diatoms) constituents. The core-catcher samples were also used for initial ${ }^{40} \mathrm{Ar} /{ }^{39} \mathrm{Ar}$ single-crystal dating of anorthoclase phenocryst analysis focusing on the lower part of the AR site.

Furthermore, core-catcher samples were subsampled for geochemical, pollen, and biomarker analyses and were used for pore-water sampling. Pore water was extracted by hydraulic squeezing, using IODP-style PTFE-titanium squeezers with Teflon disks (Manheim, 1966). Pore-water samples were divided into three aliquots. (1) Salinity and $\mathrm{pH}$ values were measured directly in the shore-based lab. (2) One aliquot for major cation measurement was acidified with $2 \% \mathrm{HNO}_{3}$ to prevent mineral precipitation. (3) An aliquot for

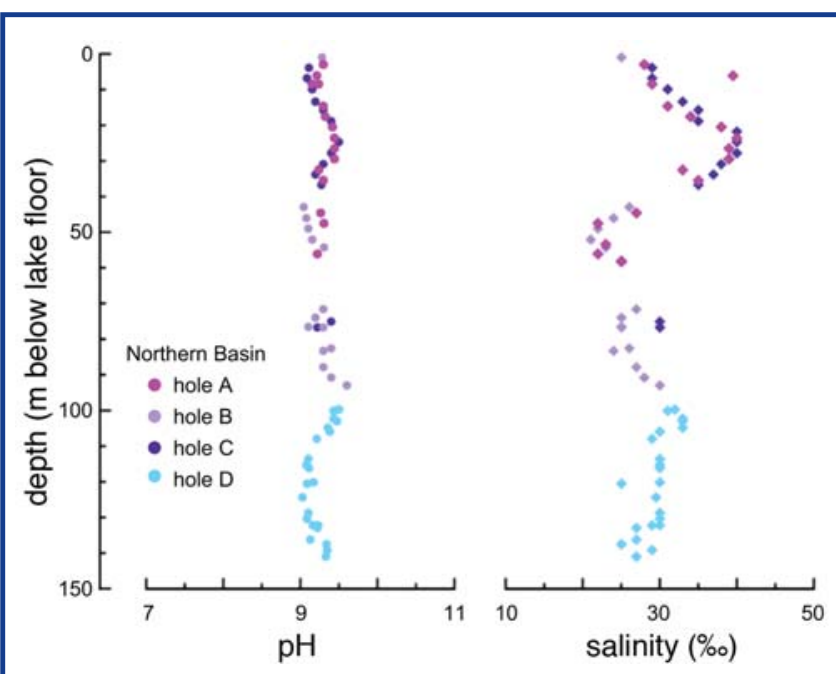

Figure 9. $\mathrm{pH}$ and salinity pore water profiles from the Northern Basin analyzed in the on-land lab. Both profiles show distinct "positive" and "negative" fluctuations with regard to recent geochemical state of Lake Van. Observed gradients can only exist over the given temporal (10-100 kyr) and spatial $(>20 \mathrm{~m})$ scales if the vertical diffusive transport is suppressed in comparison to diffusive exchange in a continuous and connected pore-water domain. At Ahlat Ridge (not shown), the pore water $\mathrm{pH}$ decreases from nearly 10 to 7 in the lowermost $40 \mathrm{~m}$ of the cores. According to preliminary results in same depth range, dissolved $\mathrm{Ca}$ and $\mathrm{Mg}$ concentrations increase continuously-most probably in response to the lower $\mathrm{pH}$-toward the bedrock.

major anions and stable isotope $\left(\delta^{18} \mathrm{O}, \delta \mathrm{D}\right)$ analyses was not preconditioned. Bulk-water anion and cation quantification as well as isotope analysis was carried out in the respective home laboratories.

The measured pore-water $\mathrm{pH}$ and salinity profiles (Fig. 9) are in agreement with the lithological analysis, and they add further evidence to the interpretation that Lake Van evolved from a Ca-carbonate dominated freshwater body with a neutral $\mathrm{pH}$ to a high-pH Na-carbonate dominated saline water body. Of particular note is the fact that $\mathrm{pH}$ and salinity values change within the sediment cores over a length of 20-50 m. Compared to modern conditions, fluctuations towards higher and lower salinity values are observed. The observed salinity (and $\mathrm{pH}$ ) gradients in the pore-water profiles indicate that the diffusive transport is strongly attenuated in the sediment column of Lake Van. Such limited exchange allows the

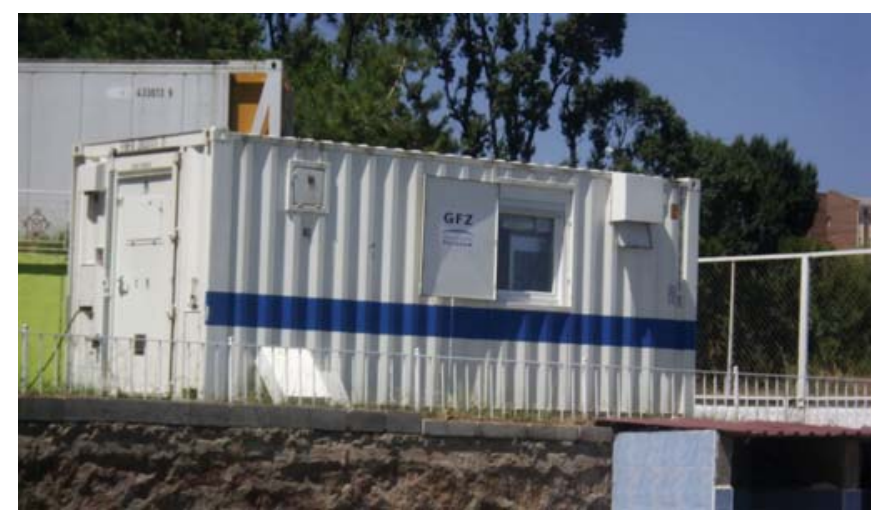

Figure 10. The mobile container laboratory BUGLab operated by GFZ Potsdam located at the shore of Lake Van during the ICDP drilling operation. 


\section{Science Reports}

conservation of the composition of the initial co-deposited lake water in the growing sediment column. These favorable "preserving" conditions offer the unique opportunity to apply the pore-water chemistry as a proxy to reconstruct the geochemical evolution of Lake Van (Tomonaga et al., 2011b, 2012).

It is interesting that the pore water of the deeper part of the drilled sections at the $\mathrm{NB}$ and AR sites shows quite different salinities: $26 \%$ at the NB and $20 \%$ at AR site
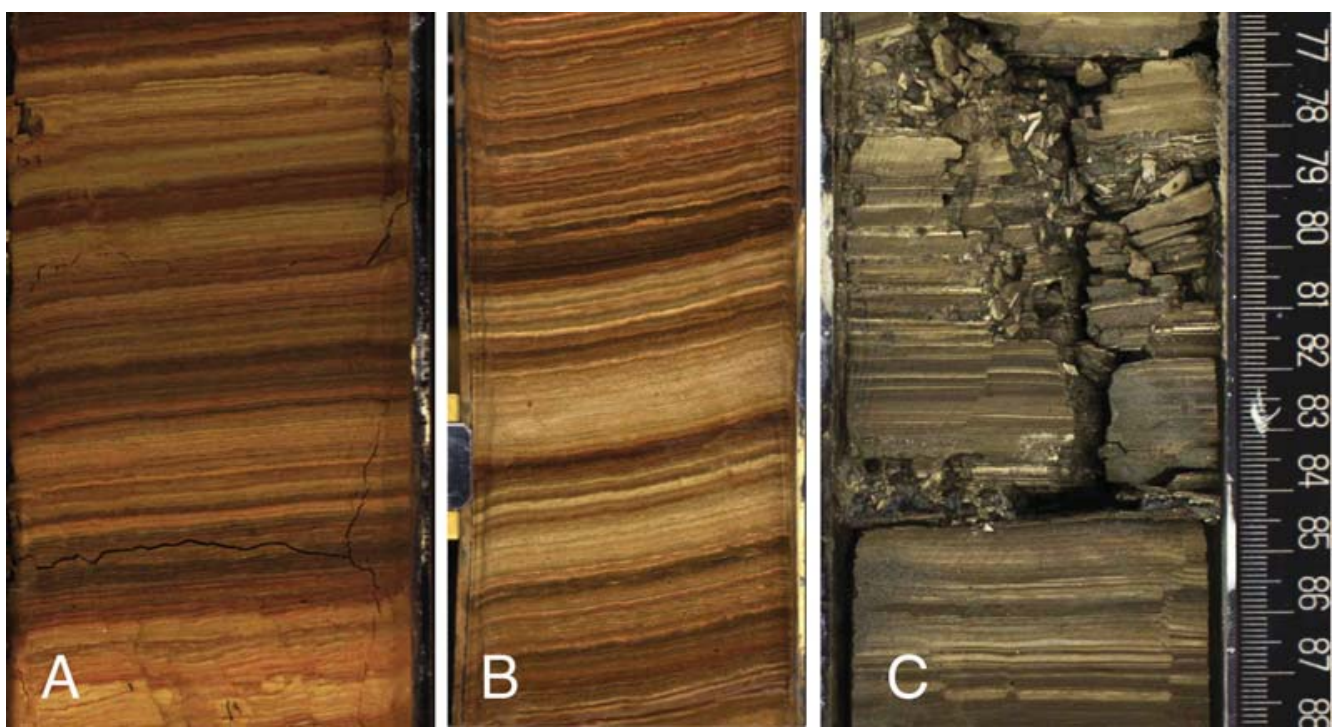

Figure 11. Three examples of finely laminated background deposits from Ahlat Ridge. The example A originates from $\sim 1 \mathrm{~m}$ depth and was deposited in the Holocene. Preliminary age data indicates that the example B (40 $\mathrm{m}$ depth) can be assigned to the last interglacial (MIS5) and the example C $(163 \mathrm{~m})$ to an older interglacial period.

(Fig. 9). These differences

suggest that the shallow

Northern Basin of Lake Van may have been disconnected from the deep Tatvan Basin during some time in Lake Van's history. Although caution does not allow us to draw any final conclusions at this point, we tentatively speculate that the observed salinity changes reflect mainly climate-controlled lake level fluctuations.
Moreover, the presence of fresher and more neutral pore waters at the Ahlat Ridge site, together with the basal lithologic succession, indicates that Lake Van did not always host saline and high-pH waters. In contrast, the lake may have been born as a common freshwater body. Only later, the lake evolved towards the present saline and high-pH water mass.
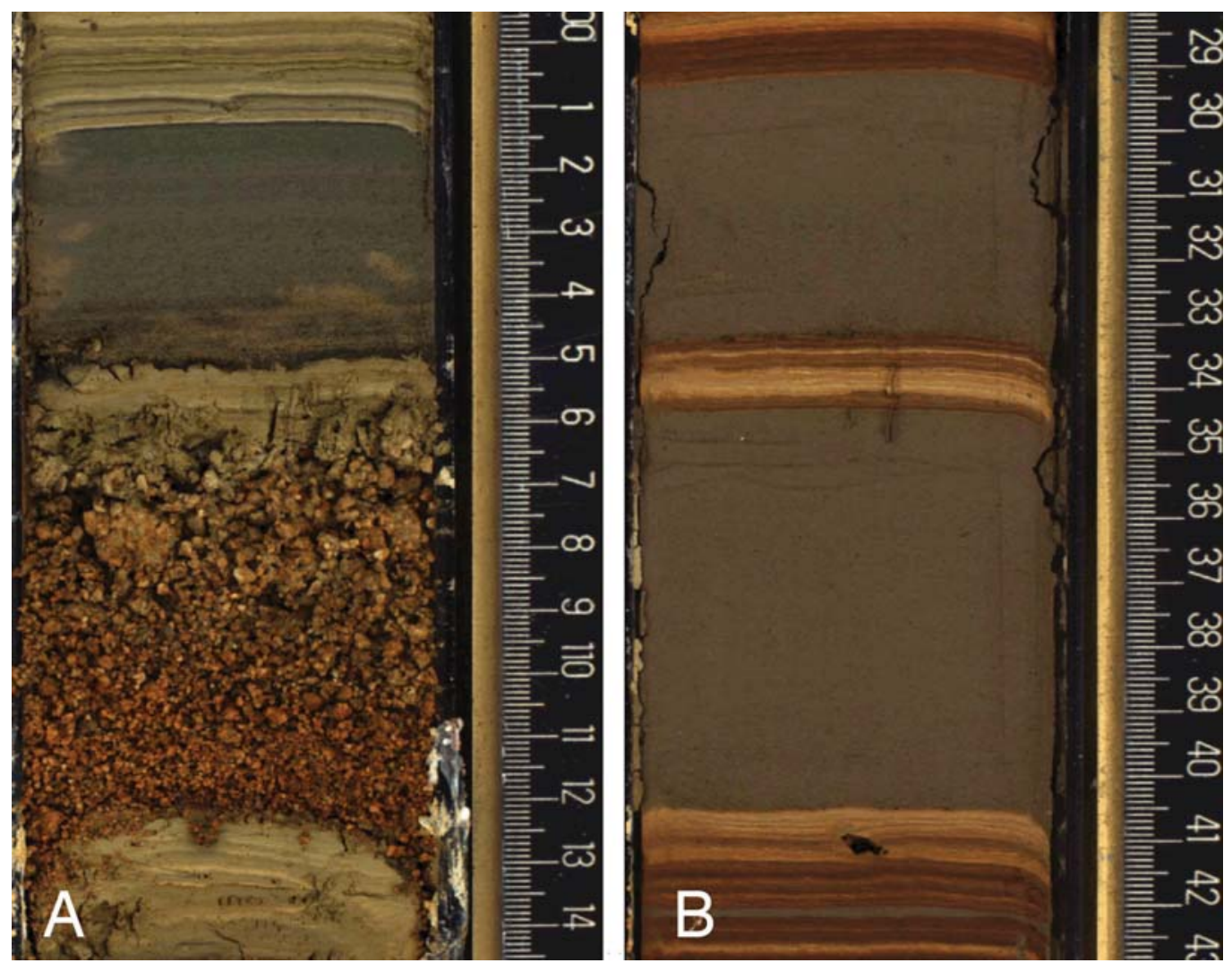

Figure 12. [A] A coarse volcaniclastic layer and a turbidite layer interrupting the continuous, laminated background sedimentation at the Ahlat Ridge site. Note the inverse grading of the pumice particles (deposition from a pumice raft). [B] Two turbidite layers interrupting the laminated sequences (Northern Basin site) consisting mostly of reworked volcaniclastic components.
The indication of limited pore-water exchange means that the dissolved pore-water species, e.g., dissolved noble gases (Blättler et al., 2011; Tomonaga et al., 2011b), may be used to geochemically reconstruct former lake levels and the past ecological state of Lake Van. For this purpose, further pore-water sampling for noble gas analysis was conducted from dedicated core sections of doubled or tripled holes, once completeness of the composite section could be predicted. To achieve these goals, 20-30-cm-long whole-round sections of the cores were sampled immediately after recovery on the drilling platform. At the AR site, $\sim 30$ sediment sections were chosen for this purpose and 
transferred into a specially designed sediment press, which allows the bulk sediment to be squeezed without being exposed to atmospheric air into small copper tube containers for noble gas analysis in the pore water of unconsolidated sediments (Brennwald et al., 2003; Tomonaga et al., 2011a). The ongoing noble gas analysis will give insight on the physical transport mechanisms of crustal and mantle derived fluids through the continental crust and on the evolution of the water exchange and salinity in the open water body of Lake Van (Tomonaga et al., 2012).

\section{Geomicrobial Analyses}

Onsite geomicrobiological investigations included cell enumeration, quantification of microbial turnover rates, and pore-water analysis. In order to obtain representative results, it is necessary to subsample and process (incubate, fix) the material immediately after retrieval of the core. For this purpose, we used the mobile geomicrobiology laboratory BUGLab of the GFZ German Research Centre for Geosciences (Fig. 10; see also Mangelsdorf and Kallmeyer, 2010). This container hosts a fully air-conditioned laboratory certified for radioisotope use, and it is equipped with fume hood, working bench, nitrogen gas supply, refrigerator, and freezer for incubation experiments and sample storage. The BUGLab is based on a standard sized 20-ft shipping container, and thus provides a functional, mobile laboratory in almost every environment (shore- or ship-based) as long as sufficient power (230-400 V) is available.

Material from undisturbed core catchers from both drilling sites was used for microbiological investigations. Subsamples for cell enumeration as well as for radioisotope incubation experiments were taken immediately when the core material arrived onshore. Samples for cell enumeration were fixed in artificial lake water including $2 \%$ formalin (Kallmeyer et al., 2008). Samples for radioisotope incubation experiments were incubated with $35 \mathrm{~S}$ sulfate for sulfate reduction rate determination (Jørgensen, 1978; Ferdelman et al., 1997). In addition, individual samples were incubated with ${ }^{14} \mathrm{C}$-methanol, ${ }^{14} \mathrm{C}$-bicarbonate, and ${ }^{14} \mathrm{C}$-acetate for quantification of methanogenesis rates and with ${ }^{14} \mathrm{C}$-methane for determination of rates of anaerobic oxidation of methane (AOM) (Ferdelman et al., 1997; Treude et al., 2005). All incubations were terminated after 3-5 days, and samples were preserved for analysis in the home lab. Additional samples for quantification of dissolved methane and for pore-water analysis were also taken from the fresh core-catcher material.

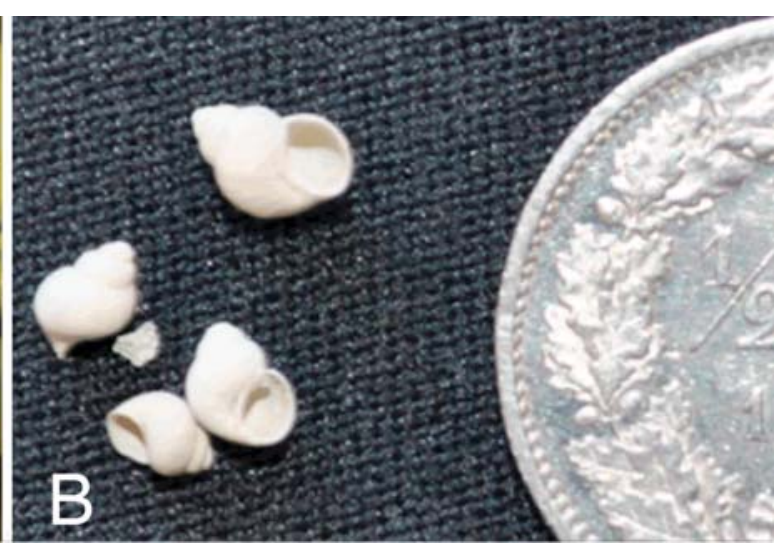

[B] Fully

\section{Sediment Lithology}

The cores were opened in spring 2011 at the IODP core repository located at the MARUM, University of Bremen. The repository's ideal facilities have been used for splitting, photographic and X-ray fluorescence (XRF) scanning of the core halves, core descriptions, and sampling. The recovered lithologies vary as predicted by the results of the pre-drilling seismic and gravity-coring survey; varved or banded lacustrine sediment sections, termed "background deposits" (Fig. 11), are intercalated by volcanic (tephra) and by event layers such as turbidites (Fig. 12). These events appear to be more abundant and thicker in the NB site than at the AR site. The frequent tephra layers guarantee the lithostratigraphic correlation of both sites and constrain the chronological framework of the recovered sediments. The NB site is characterized by much higher sedimentation rate; in fact, the base of the NB site at $143 \mathrm{~m}$ can be correlated to $\sim 2 \mathrm{~m}$ at the AR site. A composite section has been established at both sites (Fig. 8), representing the best possible complete sediment succession. Whereas the major parts of both drill sites are characterized by one of the three endmember lithologies (background deposits, event and volcanic layers; Fig. 8), the basal unit at AR is characterized by a marked downcore change in lithology. Just above the contact between the

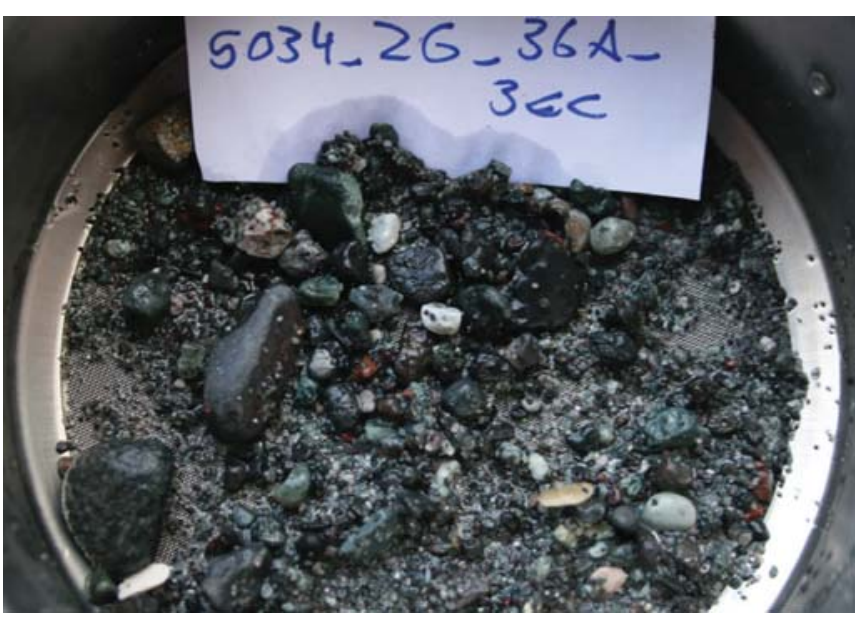

Figure 14. Washed samples of a core catcher of the basal gravel layers. The rounded nature of the gravel indicates coastal or fluvial reworking related to initial lake transgression. 
lacustrine sediments and the bedrock, zebra mussel (Dreissena) shells, which can only live in fresh or brackish waters, were found within coarse sand and gravel (Fig. 13a). Moreover, perfectly preserved and intact shells of freshwater gastropods (Bithynia) occur at a depth of $\sim 190 \mathrm{~m}$, i.e., $\sim 30 \mathrm{~m}$ above the basement (Fig. 13b). The presence especially of Bithynia shells in the sedimentological record indicates that Lake Van contained freshwater at low $\mathrm{pH}$ in the very early days, as confirmed by the pore-water analysis (see above). These basal sediments are underlain by coarse and rounded gravel layers (Fig. 14) indicative of coastal or fluvial origin. Together with the seismic prediction of an acoustic basement at around this depth, these patterns indicate that
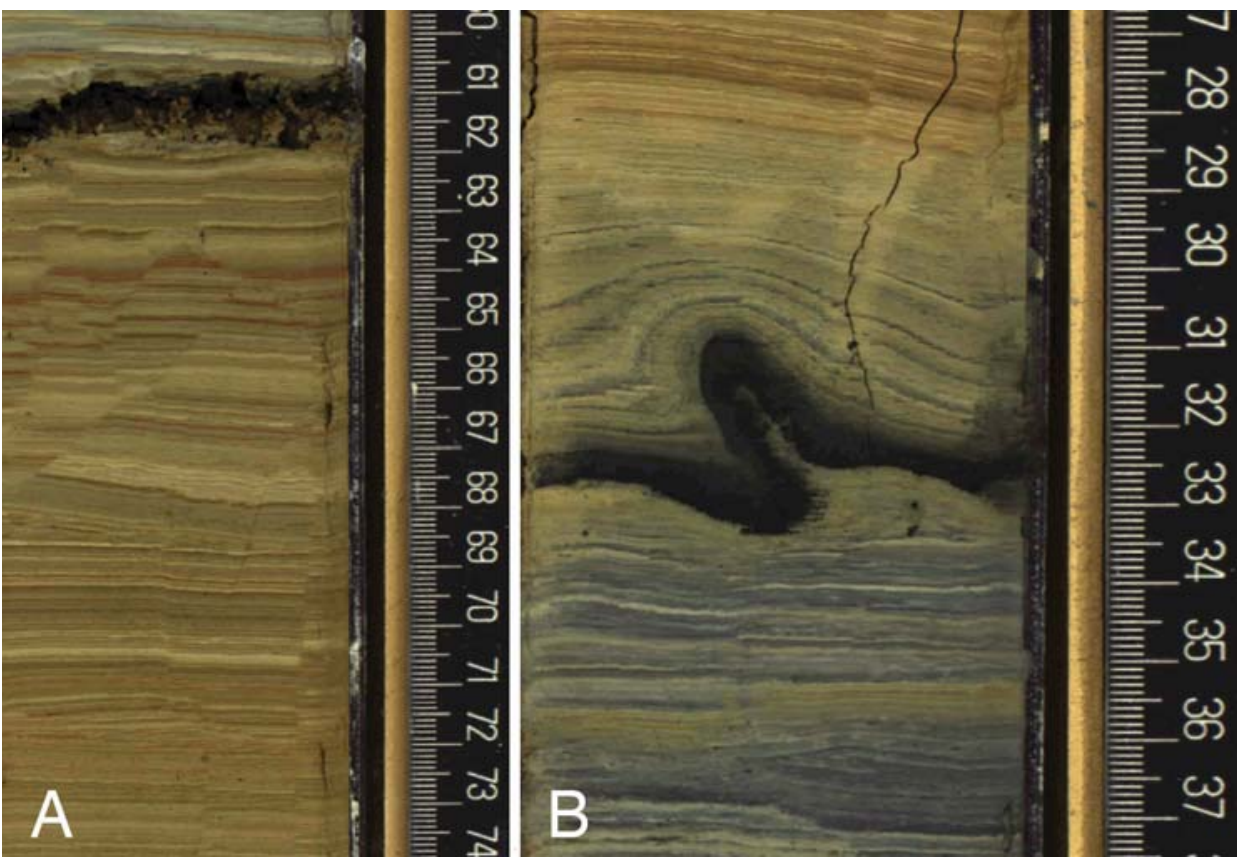

Figure 15. Examples of paleoseismic deformations in the cores. [A] Microfaults dissecting the finely laminated succession. They are only considered of paleoseismic significance if they occur in parallel cores at the same horizons, so that drilling artifacts can be ruled out. [B] Fine tephra layer that has been deformed in a microfold, indicating slumping, potentially induced by seismic shaking. the drill hole penetrated the initial transgressive phase of Lake Van upon its early creation, and it appears that the retrieved cores hold the entire geological, geochemical, volcanic, seismic, hydrological, and bio-geochemical environmental history of Lake Van starting from its very beginning up to recent. Reaching this basal succession at AR was one of the highlights of the drilling activities as, this boundary marks the birth of Lake Van.

\section{Paleoseismic Deformation Structures}

The partly annually-laminated sedimentary record down to $220 \mathrm{~m}$ also contains an invaluable record of past earthquake activities. Various forms of paleoseismites can be easily identified in the finely-laminated sedimentary sequences. Most common are complex multiple microfaults dissecting the laminations (Fig. 15a). Some of them are lined with coarser, mostly volcanic sand grains, which can be explained by liquefaction processes induced by seismic shaking. In addition, several microfolds can be seen (Fig. 15b), reflecting slumping and sliding processes also indicative of seismic shaking. Up to three parallel cores allow us to rank the observed deformation structures in terms of reliability. Deformation structures are often detected in each of the three parallel cores retrieved per site. Such multiple occurrences are used as criteria to interpret seismic shaking as a deformation trigger, as 
single occurrences could also be drilling artifacts. The mapping of these deformation features in the cores will allow us to establish a paleoseismic event catalogue shedding light on recurrence rates and intensities of strong events throughout the past.

In this context, the vulnerability of the area to seismic hazards was dramatically documented by the occurrence of the devastating 2011 M7.2 earthquake near the city of Van.

\section{Integration of Core and Seismic Data}

The integration of core data and high-resolution seismic profiles provides a reliable basis for extrapolation of the stratigraphic information over the lake basin. This allows a detailed analysis of the general sedimentary evolution of Lake Van.

Core logging data was used to generate synthetic seismograms for the synthetic-to-well ties that help to obtain two-way travel time-depth relationships at the well locations. This approach aims to extrapolate the stratigraphy from wells to the 3D space by using the seismic data. The SynPAK module (Kingdom Suite software, http://www.seismicmicro.com) was used to construct synthetic seismograms. The results show good correlations between synthetic and real seismic data in both AR and NB sites (Fig. 16). Strong marker horizons correlate well with prominent and dated tephra layers that were also correlated between the two sites. The geologic age data for the drilled horizons will eventually be assigned to the seismic stratigraphic horizons.

\section{Chronostratigraphy}

The recovered tephra layers are dominated by Süphan tephras in the deeper sections and Nemrut tephras in the shallower sections. Süphan rhyolitic and dacitic tephras carry plagioclase with low radiogenic yield, while Nemrut tephras are alkaline rhyolites and trachytes carrying anorthoclase as felsic phase. Although physical dating of the deeper part of the section is thus more difficult, preliminary single-crystal argon dating of anorthoclase suggests that the AR record encompasses more than 500,000 years of paleoenvironmental and volcanic/geodynamic history (Sumita et al., 2012). Feldspars in the freshwater basement volcaniclastic sediments are as old as $16 \mathrm{Ma}$, reflecting earlier post-collisional volcanism in the area. This general age frame is confirmed by initial geochemical results, as well as pollen analyses, which indicate repetitive changes at the glacial-interglacial scale (Fig. 17). Including the current interglacial stage, four to five interglacial stages can be identified by investigating the lithological pattern, total organic carbon concentrations, and pollen data. Laminated sections rich in total organic carbon and tree pollen are indicative of warmer environments, and they represent marine isotope stages $1,5,7,9$, and 11 or 13 that dot the last half million years of paleoclimate history. In contrast, non-laminated sec- tions, poor in organic carbon with higher amounts of steppe plants, are indicative of cold conditions and represent glacial periods.

\section{Outlook on Post-drill Science}

A detailed geochronological frame for the long continental record drilled during the PALEOVAN project in 2010 is presently being obtained through varve counting, radiocarbon dating of terrestrial organic matter, ${ }^{40} \mathrm{Ar} /{ }^{39} \mathrm{Ar}$ single crystal dating of tephra layers, $\mathrm{Th} / \mathrm{U}$ dating (aragonite laminae), paleomagnetic measurements, $10 \mathrm{Be}$, OSL/TL and orbital tuning/oxygen-isotope stratigraphy. A precise chronology is a precondition for the analysis of the climate signal in the Lake Van record, which has the potential to reveal signals with frequencies higher than Milankovitch cycles such as North Atlantic Oscillation or Dansgaard-Oeschger cycles. These signals will be documented by high-resolution XRF data. Lower frequency signals (Milankovitch) will be investigated through spectral analysis on the downhole logging data so that cyclicities and sedimentation rates can be investigated. Additional information will be obtained through mineralogical, geochemical, and paleontological analysis as well as the analyses of organic material and its composition using biomarkers such as long-chain alkenones, n-alkanes, alcohols, or fatty acids. Reliable reconstructions of Quaternary climate evolution are essential for understand-ing past climate dynamics and for validating general circulation models used to simulate future climate scenarios. Botanical data based on pollen analysis are well established as proxy data, because plants strongly depend on climate, of which temperature and precipitation are decisive factors for the survival and prospering of plants. Botanical-climatological transfer functions will be used for quantitative paleoclimate reconstructions based on the partly annually-laminated sediments of Lake Van for the last $>500$ kyr. Data-model comparisons are useful to test these results, as shown by Kaspar et al. (2005). In summary, this successful ICDP drilling campaign yielded a rich, temporally long and

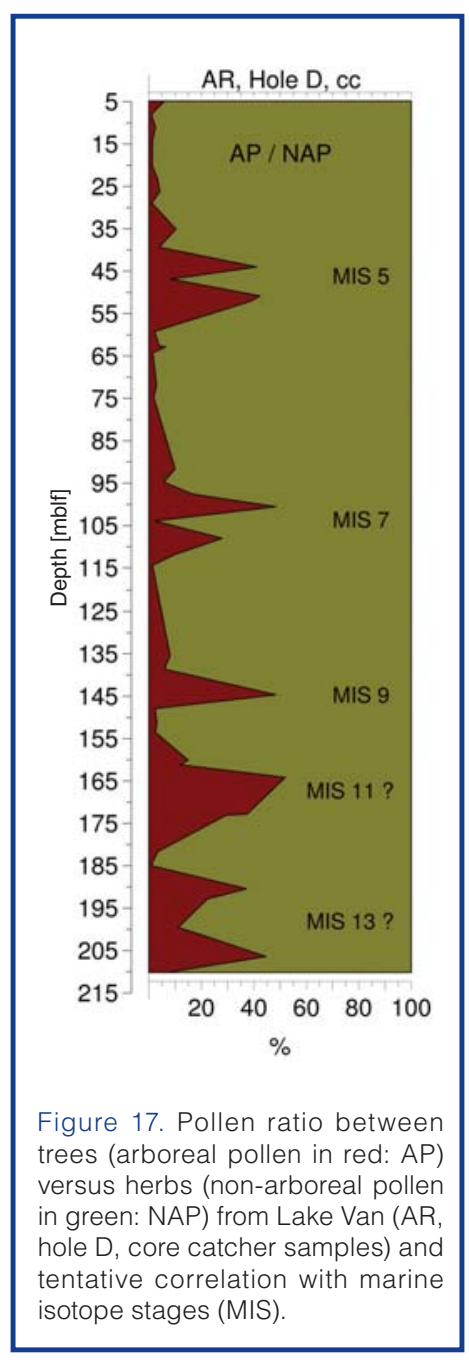


mostly continuous Lake Van sedimentary succession. This continental record, investigated through a multiproxy approach, has the potential to unravel a large suite of environmental processes occurring in a critical region so far lakking a reliable geological archive of the recent past.

\section{Acknowledgments}

Financial support has been provided by ICDP, the German Research Foundation, the Swiss National Science Foundation, and Turkey's Tübitak. We are grateful to DOSECC and its personnel for recovering the drill cores under partly difficult conditions. We thank the Integrated Ocean Drilling Program and the Bremen Core Repository (MARUM) for logistical support and core curation. Without the tremendous support from the whole Paleovan scientific team (http:// www.paleo van.info/index.php?a=steam), from many local helpers, and from the Turkish authorities, drilling would not have been such a success.

\section{References}

Blättler, R., Tomonaga, Y., Brennwald, M.S., Kwiecien, O., and Kipfer, R., 2011. Are noble gases in the sediment pore water of Lake Van promising proxies for paleoclimate conditions? Mineralogical Magazine, 75(3):532 (abstract).

Brennwald, M., Hofer, M., Peeters, F., Aeschbach-Hertig, W., Strassmann, K., Kipfer, R., and Imboden, D., 2003. Analysis of dissolved noble gases in the porewater of lacustrine sediments. Limnol. Oceanogr. Methods, 1:51-62. doi:10.4319/ lom.2011.1.51

Degens, E.T., and Kurtman, F., 1978. The Geology of Lake Van. Ankara (MTA Press).

Djamali, M., de Beaulieu, J.-L., Shah-hosseini, M., Andrieu-Ponel, V., Ponel, P., Amini, A., Akhani, H., et al., 2008. A late Pleistocene long pollen record from Lake Urmia, NW Iran. Quat. Res., 69:413-420.

Ferdelman, T.G., Lee, C., Pantoja, S., Harder, J., Bebout, B.M., and Fossing, H., 1997. Sulfate reduction and methanogenesis in a Thioploca-dominated sediment off the coast of Chile. Geochim. Cosmochim. Acta, 61(15):3065-3079. doi:10.1016/ S0016-7037(97)00158-0

Huguet, C., Fietz, S., Moraleda, N., Stockhecke, M., Anselmetti, F.S., Sturm, M., Litt, T., Heumann, G., and Rosell-Melé, A., 2012. A seasonal cycle of terrestrial inputs in Lake Van, Turkey. Environ. Sci. Pollut. Res. Int., 19(8):3628-3635. doi:10.1007/ s11356-012-0948-3

Huguet, C., Fietz, S., Stockhecke, M., Strum, M., Anselmetti, F.S., and Rosell-Mele, A., 2011. Biomarker seasonality study in Lake Van, Turkey. Org. Geochem., 42(11):1289-1298. doi:10.1016/j.orggeochem.2011.09.007

Jørgensen, B.B., 1978. A comparison of methods for the quantification of bacterial sulfate reduction in coastal marine sediments. Geomicrobiol.J., 1(1):11-27.doi:10.1080/01490457809377721

Kaden, H., Peeters, F., Lorke, A., Kipfer, R., Tomonaga, Y., and Karabiyikoglu, M., 2010. The impact of lake level change on deep-water renewal and oxic conditions in deep saline Lake Van, Turkey. Water Resour. Res., 64:W11508.

Kadioĝlu, M., Şen, Z., and Batur, E., 1997. The greatest soda-water lake in the world and how it is influenced by climatic change. Ann. Geophysicae, 15:1489-1497. doi:10.1007/s00585997-1489-9

Kallmeyer, J., Smith, D.C., Spivack, A.J., and D’Hondt, S., 2008. New cell extraction procedure applied to deep subsurface sediments. Limnol. Oceanogr. Methods, 6:236-245. doi:10.4319/ lom.2008.6.236

Kaspar, F., Kühl, N., Cubasch, U., and Litt, T., 2005. A model-data comparison of European temperatures in the Eemian interglacial. Geophys. Res. Lett., 32:L11703. doi:10.1029/ 2005GL022456

Keskin, M., 2003. Magma generation by slab steepening and breakoff beneath a subduction-accretion complex: An alternative model for collision-related volcanism in Eastern Anatolia, Turkey. Geophys. Res. Lett., 30:8046. doi:10.1029/ 2003GL018019

Kipfer, R., Aeschbach-Hertig, W., Baur, H., Hofer, M., Imboden, D.M., and Signer, P., 1994. Injection of mantle type helium into Lake Van (Turkey): The clue for quantifying deep water renewal. Earth Planet. Sci. Lett., 125(1-4):357-370. doi:10.1016/0012-821X(94)90226-7

Landmann, G., Reimer, A., Lemcke, G., and Kempe, S., 1996. Dating Late Glacial abrupt climate changes in the $14,570 \mathrm{yr}$ long continuous varve record of Lake Van, Turkey. Palaeogeogr. Palaeoclimatol. Palaeoecol., 122(1-4):107-118. doi:10.1016/ 0031-0182(95)00101-8

Lemcke, G., and Sturm, M., 1997. $\delta^{18} \mathrm{O}$ and trace element measurements as proxy for the reconstruction of climate changes at Lake Van (Turkey): Preliminary results. In Dalfes, H.N., Kukla, G., and Weiss, H. (Eds.), Third Millennium BC Climate Change and Old World Collapse. NATO ASI Series I, Global Environmental Change 49: Berlin (Springer), 653-78.

Litt, T., Anselmetti, F.S., Cagatay, M.N., Kipfer, R., Krastel, S., and Schmincke, H.-U., 2011. A 500,000-year-long sedimentary archive drilled in Eastern Anatolia. Eos, 92:477-479. doi:10.1029/2011E0510002

Litt, T., Krastel, S., Sturm, M., Kipfer, R., Örcen, S., Heumann, G., Franz, S.O., Ülgen, U.B., and Niessen, F., 2009. 'PALEOVAN', International Continental Scientific Drilling Program, (ICDP): Site survey results and perspectives: Quat. Sci. Rev., 28(15-16):1555-1567. doi:10.1016/j. quascirev.2009.03.002

Mangelsdorf, K., and Kallmeyer, J., 2010. Integration of deep biosphere research into the International Continental Scientific Drilling Program. Sci. Drill., 10:46-55. doi: 10.2204/iodp. sd.10.0.2010

Manheim, F.T., 1966. A hydraulic squeezer for obtaining interstitial water from consolidated and unconsolidated sediments. U.S. Geol. Surv. Prof. Pap., 550-C:256-261.

Melles, M., Brigham-Grette, J., Minyuk, P., Koeberl, C., Andreev, A., Cook, T., Fedorov, G., et al., 2011. The Lake El'gygytgyn Scientific Drilling Project conquering Arctic challenges in continental drilling. Sci. Drill., 11:29-40. doi:10.2204/iodp. sd.11.03.2011

Melles, M., Brigham-Grette, J., Minyuk, P., Nowaczyk, N.R., Wennrich, V., DeConto, R.M., Anderson, P.M., et.al., 2012. 2.8 million years of Arctic climate change from Lake El'gygytgyn, NE Russia. Science, 20(337):315-320. doi:10.1126/science. 1222135 
Ohlendorf, C., Gebhardt, C., Hahn, A., Kliem, P., and Zolitschka, B., 2011. The PASADO core processing strategy - A proposed new protocol for sediment core treatment in multidisciplinary lake drilling projects. Sed. Geol., 239(1-2):104-115. doi:10.1016/j.sedgeo.2011.06.007

Şengör, A.M.C., Özeren, S., Genec, T., and Zor, E., 2003. East Anatolian high plateau as a mantle supported, north-south shortened domal structure. Geophys. Res. Lett., 30(24):8045. doi:10.1029/2003GL017858

Stockhecke, M., Anselmetti, F.S., Meydan, A.F., Odermatt, D., and Sturm, M., 2012. The annual particle cycle in Lake Van (Turkey). Palaeogeogr. Palaeoclimatol. Palaeoecol., 333-334:148-159. doi:10.1016/j.palaeo.2012.03.022

Sumita, M., Schminke, H.-U., and the PaleoVan Scientific Team, 2012. The climatic, volcanic and geodynamic evolution of the Lake Van-Nemrut-Süphan system (Anatolia) over the past 550-600000 years: a progress report based on a study of the products of explosive volcanism on land and in the lake. Annual ICDP/IODP DFG Kolloquium, Kiel, Extended abstract, 157-162.

Tomonaga, Y., Blättler, R., Brennwald, M.S., and Kipfer, R., 2012. Interpreting noble-gas concentrations as proxies for salinity and temperature in the world's largest soda lake (Lake Van, Turkey). J. Asian Earth Sci., in press. doi:10.1016/j. jseaes.2012.05.011

Tomonaga, Y., Brennwald, M.S., and Kipfer, R., 2011a. An improved method for the analysis of dissolved noble gases in the porewater of unconsolidated sediments. Limnol. Oceanogr. Methods, 9:42-49.

Tomonaga, Y., Brennwald, M.S., and Kipfer, R., 2011b. Spatial distribution and flux of terrigenic He dissolved in the sediment porewater of Lake Van (Turkey). Geochim. Cosmochim. Acta, 75(10):2848-2864. doi:10.1016/j.gca.2011.02.038

Treude, T., Niggemann, J., Kallmeyer, J., Wintersteller, P., Schubert, C.J., Boetius, A., and Jørgensen, B.B., 2005. Anaerobic oxidation of methane and sulfate reduction along the Chilean continental margin. Geochim. Cosmochim. Acta, 69(11):2767-2779. doi:10.1016/j.gca.2005.01.002

Tzedakis, P.C., Andieu, V., Birks, H.J.B., de Beaulieu, J-L., Crowhurst, S., Follieri, M., Hooghiemstra, H., et al., 2001. Establishing a terrestrial chronological framework as a basis for biostratigraphical comparisons. Quat. Sci. Rev., 20(16-17):1583-1592. doi:10.1016/S0277-3791(01)00025-7

Wick, L., Lemcke, G., and Sturm, M., 2003. Evidence of Lateglacial and Holocene climatic change and human impact in eastern Anatolia: High-resolution pollen, charcoal, isotopic and geochemical records from the laminated sediments of Lake Van, Turkey. The Holocene, 13(5):665-675. doi:10.1191/ 0959683603h1653rp

\section{Authors}

Georg Heumann, Thomas Litt, and Nadine Pickarski, Steinmann Institute of Geology, Mineralogy and Paleontology, Bonn University, Bonn, Germany, e-mail: t.litt@uni-bonn.de

Deniz Cukur, Sebastian Krastel, Hans-Ulrich Schmincke, and Mari Sumita, GEOMAR, Helmholtz Centre for Ocean Research Kiel, Wischhofstr. 1-3, 24148 Kiel, Germany
Flavio S. Anselmetti, Jürg Beer, Gerald Haug, Rolf Kipfer, Ola Kwiecien, Marie-Eve Randlett, Carsten J. Schubert, Mona Stockhecke, Mike Sturm, and Yama Tomonaga, Eawag, Swiss Federal Institute of Aquatic Science and Technology, Dübendorf and Kastanienbaum, Switzerland, e-mail: flavio.anselmetti@geo.unibe.ch

A. Feray Meydan, and Sefer Orcen, Yüzüncü Yıl Üniversitesi, Mühendislik - Mimarlık Fakültesi Jeoloji Mühendisliği Bölümü, Van, Turkey

Namik Cagatay, and Emre Damci, Department of Geological Engineering and Eastern Mediterranean Centre for Oceanography and Limnology, Istanbul Technical University, Istanbul, Turkey

Henrike Baumgarten, and Thomas Wonik, LeibnizInstitute for Applied Geophysics (LIAG), Hannover, Germany

Clemens Glombitza, and Jens Kallmeyer, Potsdam University, Institute for Earth and Environmental Sciences, Geomicrobiology Group, Potsdam, Germany

Luigi Vigliotti, Istituto di Scienze Marine, ISMAR-CNR, Bologna, Italy

and the PALEOVAN Scientific Team

\section{Photo Credits}

Fig. 7: Flavio Anselmetti, University of Bern

Fig. 10: Jens Kallmeyer, GFZ Potsdam

Fig. 11: PALEOVAN science team

Fig. 12: PALEOVAN science team

Fig. 13: PALEOVAN science team

Fig. 14: PALEOVAN science team

Fig. 15: ALEOVAN science team

\section{Related Web Link}

http://www.paleovan.info/

http://www.dosecc.org/index.php/equipment/deep-lake -drilling-system-dlds 